\title{
PENGARUH MOTIVASI, KEPUASAN, DAN SIKAP KERJA TERHADAP KINERJA KARYAWAN DI CAFÉ X BOGOR
}

\author{
Agung Gita Subakti \\ Hotel Management Department, Faculty of Economic and Communication, BINUS University \\ Jln. K. H. Syahdan No. 9, Palmerah, Jakarta Barat 11480 \\ agsubakti@binus.edu
}

\begin{abstract}
HR management is an effort to integrate the needs of personnel with organization's objectives to increase the contribution that can be given by the employees of the organization towards the achievement of goals. This research examined the effect of motivation, job satisfaction, and working attitude to job performance on Café X's employees, Bogor. The use of these variables is expected to solve the performance problem on the employees. The respondents of this study were 25 employees using sampling techniques survey. The Research method used are literature and empirical (survey) approach, and the multiple regression statistical analysis. The analysis showed that working attitude and motivation have a positive effect on employee performance, with the closeness of the relationship in the medium category. To working attitude variable, the highest dimension is cognitive component and the lowest is behavior component. To motivation variable, the highest dimension is physical dimension and the lowest is self-actualization. While job satisfaction does not significantly influence on employee performance. Compensation becomes the major factor to dissatisfaction and the lowest is promotion factor. These empirical findings indicate that the restaurant management needs an improvement in order to improve the performance of employees, especially to evaluate compensation policies and the provision of incentives.
\end{abstract}

Keywords: motivation, satisfaction, working attitude, employee performance

\begin{abstract}
ABSTRAK
MSDM merupakan suatu upaya pengintegrasian kebutuhan personel dengan tujuan organisasi, yaitu peningkatan kontribusi yang dapat diberikan oleh para pekerja dalam organisasi ke arah tercapainya tujuan. Penelitian ini menguji pengaruh motivasi, kepuasan, dan sikap kerja terhadap kinerja karyawan Café X, Bogor. Penggunaan variabel tersebut diharapkan dapat memecahkan permasalahan kinerja karyawan Café X, Bogor. Responden penelitian ini adalah 25 karyawan Café X dengan menggunakan teknik pengambilan sampel survei. Metode analisis menggunakan metode kepustakaan dan empiris dengan pendekatan survei (kuesioner), dan analisis statistik regresi berganda. Hasil analisis menunjukkan bahwa sikap kerja dan motivasi kerja berpengaruh positif terhadap kinerja pegawai, dengan keeratan hubungan dalam kategori sedang. Untuk variabel sikap kerja, dimensi tertinggi ada pada komponen kognitif, dan paling rendah ada pada komponen perilaku. Untuk variabel motivasi, dimensi tertinggi ada pada kebutuhan fisik dan terendah dimensi aktualisasi diri. Sedangkan kepuasan kerja tidak berpengaruh penting terhadap kinerja karyawan. Di sini faktor kompensasi menjadi faktor utama terhadap ketidakpuasan dan terendah faktor promosi jabatan. Temuan empiris ini mengindikasikan bahwa manajemen restaurant perlu melakukan perbaikan dalam upaya meningkatkan kinerja pegawai, terutama melakukan evaluasi kebijakan kompensasi serta adanya pemberian insentif.
\end{abstract}

Kata kunci: motivasi, kepuasan, sikap kerja, kinerja karyawan 


\section{PENDAHULUAN}

Era sekarang masalah Manajemen Sumber Daya Manusia (MSDM) menjadi hal yang menarik untuk dipelajari karena berkaitan dengan produktivitas kerja pegawai. MSDM sendiri merupakan suatu upaya pengintegrasian kebutuhan personel dengan tujuan organisasi, yaitu peningkatan kontribusi yang dapat diberikan oleh para pekerja dalam organisasi ke arah tercapainya tujuan. Fungsi operasional yang dimiliki MSDM di antaranya adalah pemeliharaan yang menitikberatkan pada pemeliharaan kondisi fisik dari pegawai, keselamatan dan kesehatan kerja serta pemeliharaan sikap menyenangkan yaitu hubungan yang harmonis. Berdasarkan hal tersebut dinyatakan bahwa pengakuan terhadap manusia senantiasa mempunyai kedudukan makin penting karena masyarakat kita menuju masyarakat yang berorientasi kerja, memandang kerja sebagai satu tugas yang harus dikerjakan dengan baik. Oleh sebab itu manusia dapat diintegrasikan secara efektif di berbagai organisasi baik menyangkut pendidikan, perusahaan, pemerintahan dan sebagainya.

Jadi dalam hal ini perusahaan harus mencari cara untuk mendorong para karyawannya untuk mempunyai kemauan dalam bekerja dan cara yang dapat dilakukan adalah dengan memotivasi para karyawannya. Motivasi kerja menurut Munandar (2008) adalah suatu proses yang di dalamnya kebutuhan-kebutuhan mendorong seseorang untuk melakukan serangkaian kegiatan yang mengarah ke tercapainya tujuan tertentu. Sedangkan Nawawi (2005) menjelaskan bahwa kata dasar motivasi adalah motif yang berarti dorongan, sebab, atau alasan seseorang melakukan sesuatu. Sehingga dapat disimpulkan bahwa motivasi selalu berhubungan dengan kebutuhan, keinginan, dan dorongan usaha untuk mencapai tujuan tertentu. Sedangkan motivasi kerja menurut Ernest L. McCormick dalam Mangkunegara (2002) mengemukakan bahwa motivasi kerja sebagai kondisi yang berpengaruh membangkitkan, mengarahkan dan memelihara perilaku yang berhubungan dengan lingkungan kerja. Menurut Anoraga (2006) menjelaskan bahwa motivasi kerja adalah sesuatu yang menimbulkan semangat atau dorongan kerja. Oleh sebab itu, motivasi kerja disebut pendorong semangat kerja. Kuat dan lemahnya motivasi kerja seorang tenaga kerja ikut menentukan besar kecil prestasi.

Selain motivasi kerja, ada hal lain yang dapat memengaruhi kinerja karyawan yaitu kepuasan kerja. Robbins dan Judge (2007) menyatakan bahwa kepuasan kerja dapat didefinisikan sebagai suatu perasaan positif mengenai suatu pekerjaan yang muncul dari sebuah evaluasi dan karakteristik individu. Wood et. al (2001) berpendapat bahwa Kepuasan kerja merupakan sebuah sikap yang dimiliki individu terhadap pekerjaannya baik itu positif maupun negatif.

Sikap kerja yang baik juga menjadi salah satu faktor yang penting agar kinerja dapat berjalan secara optimal. Menurut Kreitner dan Kinicki (2008), dijelaskan bahwa sikap kerja adalah suatu kecenderungan yang dipelajari untuk merespons secara konsisten terhadap sikap yang menyenangkan dan tidak menyenangkan dengan rasa menghargai kepada suatu objek tertentu. Menurut George dan Jones (2005), sikap kerja adalah kumpulan perasaan, kepercayaan, dan pemikiran tentang cara berperilaku yang dipegang oleh seseorang tentang pekerjaan dan organisasinya.

Penelitian memilih Café X, Bogor, sebagai objek penelitian. Café X adalah restoran yang buka selama $24 \mathrm{jam} / \mathrm{hari}, 7 \mathrm{hari} / \mathrm{minggu}$, dengan kapasitas ruangan dapat menampung 70 orang ditambah 16 kursi di ruang VIP. Café X menyajikan menu buffet untuk sarapan, makan siang, dan makan malam dengan pilihan menu yang cukup beragam mulai dari jenis masakan Indonesia hingga internasional. Dikarenakan beroperasi selama 24 jam/hari dan 7 hari/minggu, hal ini menjelaskan bahwa Café X buka tanpa ada hari libur. Untuk menjaga konsistensi dari menu dan pelayanan yang disajikan oleh para karyawan Café X, diperlukan kinerja yang optimal baik dari sumber daya manusia, dalam hal ini karyawan sebagai penghubung antara dapur dengan konsumen, untuk menjaga kualitas pelayanan agar kepuasan tamu dapat terpenuhi. 
Dalam pelaksanaannya, bukan tidak mungkin terjadi motivasi kerja yang menurun pada karyawan Café X yang dapat juga timbul dari rendahnya kepuasan kerja karyawan tersebut. Ini berarti dapat memengaruhi kinerja karyawan dalam melakukan pelayanan, yang juga menurunnya kualitas pelayanan kepada para tamu yang menginap di Hotel Salak the Heritage Bogor dan makan di Café X. Kemungkinan yang sangat fatal dapat terbayangkan bila kinerja karyawan Café $\mathrm{X}$ tersebut menurun akibat rendahnya motivasi kerja dan rendahnya kepuasan kerja mereka. Hal ini tercermin dari penelitian pendahuluan melalui survei terhadap beberapa pegawai yang berhasil ditemui. Di sisi lain sikap kerja yang kurang baik bisa timbul karena rendahnya motivasi kerja dan kepuasan kerja yang tidak tercapai. Jika bukan karena faktor lain, masalah sikap kerja ini juga dapat memengaruhi kinerja karyawan dalam memberikan pelayanan kepada konsumen sehingga keluhan dari konsumen muncul. Hal ini menjadi berdampak kurang baik bagi perusahaan.

Berdasarkan latar belakang tersebut, maka penelitian mengambil judul Pengaruh Motivasi, Kepuasan, dan Sikap Kerja terhadap Kinerja Karyawan di Café X, Bogor. Dengan perumusan masalah adalah tentang pengaruh motivasi terhadap kinerja karyawan Café $\mathrm{X}$, Bogor; pengaruh kepuasan terhadap kinerja karyawan Café X, Bogor; pengaruh sikap kerja terhadap kinerja karyawan Café X, Bogor; pengaruh motivasi, kepuasan, dan sikap kerja secara simultan terhadap kinerja Karyawan Café $\mathrm{X}$, Bogor. Maksud dan tujuan riset adalah untuk memperoleh bukti empiris mengenai ada atau tidaknya pengaruh yang signifikan dari motivasi, kepuasan, dan sikap kerja terhadap kinerja karyawan Café X Bogor dan memberikan rekomendasi untuk perbaikan kinerja karyawan di Café X tersebut.

\section{METODE PENELITIAN}

Agar terdapat suatu pemahaman yang utuh terhadap kajian motivasi kerja, kepuasan kerja, dan sikap kerja terhadap kinerja karyawan, penelitian dituangkan dalam bentuk model kerangka pemikiran. Dapat dikatakan bahwa motivasi kerja, kepuasan kerja, dan sikap kerja terhadap kinerja karyawan mempunyai hubungan yang erat. Sehingga satu dengan yang lainnya tidak dapat dipisahkan. Hal ini disajikan dalam gambar berikut.

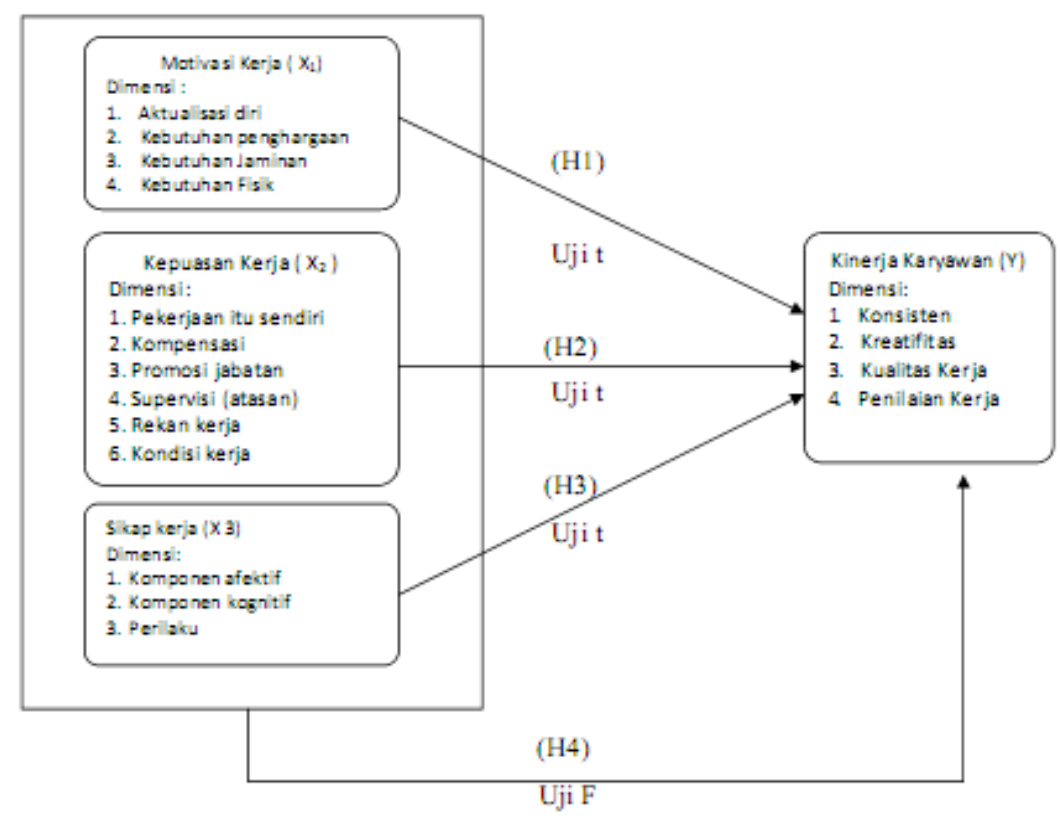

Gambar 1 Kerangka Pemikiran 
Berdasarkan kerangka pemikiran seperti pada Gambar 1, penelitian mengkaji variabel motivasi kerja (x1), kepuasan kerja (x2), dan sikap kerja (x3) serta pengaruhnya terhadap kinerja karyawan (y) yang dianalisis dengan menggunakan pendekatan statistik regresi berganda, jika ada pengaruh positif baik secara parsial maupun simultan dari variabel bebas terhadap variabel terikat.

\section{Perumusan Hipotesis Penelitian}

Hipotesis yang diajukan dalam penelitian adalah sebagai berikut.

\section{Hipotesis Nol:}

$\mathrm{H}_{0} 1$ tidak ada pengaruh motivasi kerja terhadap kinerja karyawan,

$\mathrm{H}_{0} 2$ tidak ada pengaruh kepuasan kerja terhadap kinerja pegawai,

$\mathrm{H}_{0} 3$ tidak ada pengaruh kualitas pelayanan terhadap kinerja pegawai,

$\mathrm{H}_{0} 4$ tidak ada pengaruh disiplin kerja, motivasi dan kualitas pelayanan secara bersama-sama terhadap kinerja pegawai.

Hipotesis Alternatif:

$\mathrm{H}_{\mathrm{a}} 1$ ada pengaruh disiplin kerja terhadap kinerja pegawai,

$\mathrm{H}_{\mathrm{a}} 2$ ada pengaruh motivasi terhadap kinerja pegawai,

$\mathrm{H}_{\mathrm{a}} 3$ ada pengaruh kualitas pelayanan terhadap kinerja pegawai,

$\mathrm{H}_{\mathrm{a}} 4$ ada pengaruh disiplin kerja, motivasi dan kualitas pelayanan secara bersama sama terhadap kinerja pegawai.

\section{HASIL DAN PEMBAHASAN}

Karakteristik responden sering kali menunjukkan kecenderungan arah tanggapan dalam menjawab pertanyaan penelitian. Tabel berikut menyajikan karakteristik data responden berdasarkan jenis kelamin, umur, pendidikan, serta lama kerja.

Tabel 1 Karakteristik Responden

\begin{tabular}{llcc}
\hline KarakteristikResponden & & Jumlah Orang & Persentase (\%) \\
\hline Jenis Kelamin : & Laki Laki & 14 & 56 \\
& Wanita & 11 & 44 \\
\hline Umur: & $<20$ tahun & 3 & 12 \\
& $20-30$ tahun & 19 & 76 \\
& $>30$ tahun & 3 & 12 \\
\hline Pendidikan: & SMP & 2 & 8 \\
& SMU/Sederajat & 17 & 68 \\
& Diploma & 4 & 16 \\
& Sarjana & 2 & 8 \\
\hline Lama kerja: & $<5$ tahun & 10 & 40 \\
& $5-10$ tahun & 13 & 52 \\
& $>10$ tahun & 2 & 8 \\
\hline
\end{tabular}

(Sumber: Café X Bogor, 2013)

Berdasarkan data Tabel 1, terlihat bahwa dari total 25 sampel responden dalam penelitian ini, komposisi responden berdasarkan demografi responden adalah sebagai berikut. (1) Jenis kelamin: responden paling banyak adalah pegawai laki-laki yaitu 14 orang $(56 \%)$; sedangkan wanita 11 orang 
(44\%). (2) Umur: responden paling banyak berada di kisaran usia 21 - 30 tahun yaitu 19 orang (76\%); sedangkan usia di bawah 20 tahun dan di atas 30 tahun masing-masing 3 orang (12\%). (3) Pendidikan: responden paling banyak adalah lulusan SMU/Sederajat yaitu 17 orang $(68 \%)$, disusul lulusan diploma 4 orang (16\%), sarjana 2 orang (8\%), dan SMP 2 orang (8\%). (4) Lama kerja: responden paling banyak adalah pegawai dengan masa kerja antara 5 - 10 tahun yaitu 13 orang (52\%); kemudian lama kerja di bawah 5 tahun ada 10 orang $(40 \%)$ dan di atas 10 tahun ada 2 orang $(8 \%)$.

\section{Uji Validitas}

Uji validitas dilakukan untuk mengetahui tingkat kevalidan dari instrumen (kuesioner) yang digunakan dalam pengumpulan data yang diperoleh dengan cara mengorelasikan setiap skor variabel jawaban responden dengan total skor masing-masing variabel. Kemudian hasil korelasi dibandingkan dengan nilai kritis pada taraf signifikan 5\%. Tinggi rendahnya validitas instrumen menunjukkan sejauh mana data yang terkumpul tidak menyimpang. Gambaran tentang variabel yang dimaksud dijelaskan dalam Tabel 2 berikut.

Tabel 2 Uji Validitas

\begin{tabular}{ccccccc}
\hline \multirow{2}{*}{$\begin{array}{c}\text { Nomor } \\
\text { Kuesioner }\end{array}$} & $\mathbf{8 1}$ & Ket. & X2 & Ket. & X3 & Ket. \\
\cline { 2 - 6 } 1 & .703 & Valid & .619 & Valid & .579 & Valid \\
2 & .687 & Valid & .459 & Valid & .062 & Tidak Valid \\
3 & .610 & Valid & .485 & Valid & .488 & Valid \\
4 & .685 & Valid & .398 & Valid & .790 & Valid \\
5 & .478 & Valid & .646 & Valid & .579 & Valid \\
6 & .431 & Valid & .746 & Valid & .472 & Valid \\
7 & .088 & Tidak Valid & .449 & Valid & & \\
8 & .703 & Valid & .719 & Valid & & \\
9 & .802 & Valid & .803 & Valid & & \\
10 & .482 & Valid & .622 & Valid & & \\
11 & & & .626 & Valid & & \\
12 & & .577 & Valid & & \\
13 & & .518 & Valid & & \\
14 & & .455 & Valid & \\
15 & & .123 & Tidak Valid & \\
\hline
\end{tabular}

(Sumber: hasil pengolahan data primer, 2013)

\section{Uji Reliabilitas}

Pengujian reliabilitas digunakan untuk melihat reliabilitas masing-masing instrumen yang digunakan dengan koefisien cronbach alpha. Menurut Ghozali (2005) dinyatakan bahwa suatu konstruksi atau variabel dikatakan reliable jika memberikan nilai cronbach alpha lebih dari 0,7. Dari hasil pengujian menggunakan program statistik SPSS versi 19, nilai cronbach alpha untuk masingmasing variabel penelitian dapat dilihat pada Tabel 3 sebagai berikut.

Tabel 3 Uji Reliabilitas

\begin{tabular}{lcccc}
\hline \multicolumn{1}{c}{ Variabel } & Cronbach Alpha & $>/<$ & $\begin{array}{c}\text { Batas } \\
\text { Minimum }\end{array}$ & Keputusan \\
\hline Motivasi Kerja & 0,849 & & & Reliabel \\
Kepuasan Kerja & 0,852 & $>$ & 0,7 & Reliabel \\
Sikap Kerja & 0,744 & & & Reliabel \\
\hline
\end{tabular}

(Sumber: hasil pengolahan data primer, 2013) 


\section{Uji Analisis Persamaan Regresi}

Analisis regresi ini digunakan untuk mengetahui kencederungan dari pengaruh variabel motivasi, kepuasan, dan sikap kerja terhadap kinerja karyawan. Berdasarkan olah data statistik, diperoleh ringkasan keluaran hasil penghitungan sebagai berikut.

Tabel 4 Nilai Koefisien Regresi

\begin{tabular}{lcc}
\hline \multicolumn{1}{c}{ Variabel $^{*}$ ) } & Koefisien Regresi & Signifikansi \\
\hline Konstanta & 14,165 & 0,000 \\
Motivasi Kerja & 0,355 & 0,008 \\
Kepuasan Kerja & 0,119 & 0,445 \\
Sikap Kerja & 0,557 & 0,191 \\
\hline
\end{tabular}

*) Variabel terikat: Kinerja

(Sumber: hasil pengolahan data statistik, 2013)

Dari Tabel di atas dapat dilihat persamaan regresinya menjadi $\mathrm{Y}=14,165+0,355 \mathrm{X}_{1}+$ $0,119 \mathrm{X}_{2}+0,557 \mathrm{X}_{3}$.

Penjelasannya adalah sebagai berikut. Pertama, jika semua variabel bebas mempunyai nilai 0 , nilai kinerja memiliki nilai 14,165 . Artinya adalah variabel kinerja tetap memiliki nilai meskipun variabel motivasi kerja, kepuasan, dan sikap kerja tidak memiliki nilai. Kedua, nilai koefisien motivasi kerja sebesar 0,355 . Artinya setiap peningkatan motivasi kerja, kinerja karyawan berubah menjadi 0,355. Nilai signifikansi 0,001 menunjukkan bahwa terdapat hubungan antara motivasi kerja dengan kinerja karyawan. Ketiga, nilai koefisien kepuasan kerja sebesar 0,119. Artinya setiap peningkatan kepuasan kerja, kinerja karyawan berubah menjadi 0,119. Koefisien regresi kepuasan kerja dengan signifikansi (p-value) 0,445 menunjukkan bahwa tidak terdapat hubungan antara kepuasan kerja dengan kinerja karyawan. Keempat, nilai koefisien sikap kerja sebesar 0,557. Artinya setiap peningkatan sikap kerja 1, kinerja karyawan berubah menjadi 0,557. Koefisien regresi dengan signifikansi 0,005 menunjukkan terdapat pengaruh positif sikap kerja terhadap kinerja karyawan.

Dari persamaan model regresi tersebut dapat dilihat bahwa nilai koefisien regresi sikap kerja lebih besar dibandingkan koefisien regresi variabel kepuasan kerja dan motivasi kerja. Hal ini dapat dikatakan bahwa kinerja lebih banyak dipengaruhi oleh sikap kerja, kemudian variabel berikutnya motivasi. Model persamaan regresi tersebut sekaligus dapat digunakan untuk menjelaskan tentang kinerja karyawan berdasarkan sikap kerja dan motivasi kerja. Setiap kenaikan sikap kerja akan memengaruhi kinerja karyawan sebesar 0,355 dan motivasi kerja akan memengaruhi kinerja karyawan sebesar 0,557. Sedangkan berdasarkan variabel kepuasan kerja tidak bisa diprediksi, mengingat tingkat variabel kepuasan kerja karyawan yang tergolong rendah, sehingga belum mampu meningkatkan kinerja secara maksimal.

\section{Uji Korelasi}

Tabel 5 berikut menjelaskan hasil uji korelasi motivasi kerja, kepuasan kerja, dan sikap kerja terhadap variabel kinerja.

Tabel 5 Nilai Korelasi dan R Square $\left(\mathrm{R}^{2}\right)$ terhadap Variabel Kinerja

\begin{tabular}{|l|c|c|c|l|}
\hline \multicolumn{1}{|c|}{ Variabel $^{*}$ ) } & R & $\mathbf{R}^{\mathbf{2}}$ & p-value & \multicolumn{1}{c|}{ Keterangan } \\
\hline Motivasi Kerja & 0,522 & 0,272 & 0,002 & Signifikan \\
\hline Kepuasan Kerja & 0,155 & 0,024 & 0,057 & Tidak Signifikan \\
\hline Sikap Kerja & 0,537 & 0,288 & 0,001 & Signifikan \\
\hline
\end{tabular}

(Sumber: hasil olahan data statistik, 2013) 
Berdasarkan Tabel 5 di atas dapat dijelaskan sebagai berikut. Variabel motivasi kerja memiliki koefisien korelasi (r) 0,522 atau $27,2 \%$ kinerja pegawai dipengaruhi oleh motivasi kerja. Ini menunjukkan motivasi kerja dari karyawan tidak optimal, sehingga pengaruhnya terhadap kinerja pegawai juga tidak maksimal. Ada beberapa faktor yang mungkin menyebabkan motivasi kerja tidak optimal, seperti faktor fisik dalam bentuk upah minimum yang masih rendah, kebutuhan akan jaminan, penghargaan yang minim, atau rendahnya untuk aktualisasi diri.

Variabel kepuasan kerja memiliki koefisien korelasi (r) 0,155 atau hanya 2,4\% kinerja pegawai dipengaruhi oleh kepuasan kerja. Hal ini menunjukkan betapa rendahnya tingkat kepuasan kerja pada pegawai. Faktor kompensasi masih menjadi faktor utama yang menjadi ketidakpuasan karyawan. Padahal kepuasan kerja merupakan suatu kondisi yang menentukan keberhasilan perusahaan dalam mencapai tujuannya. Sebaliknya jika kepuasan kerja karyawan rendah, hal itu akan menimbulkan konsekuensi buruk pula terhadap tujuan perusahaan sehingga tidak dapat bersaing dengan perusahaan lain.

Variabel sikap kerja memiliki koefisien korelasi (r) 0,537 atau 28,8\% kinerja pegawai dipengaruhi oleh sikap kerja. Tingginya pengaruh sikap kerja terhadap kinerja dibanding variabel motivasi dan kepuasan ini mencerminkan adanya suatu kecenderungan positif dalam merespons kondisi atau suasana lingkungan kerja serta adanya rasa menghargai terhadap manajemen di tempat kerja atau faktor-faktor internal atau eksternal lainnya.

\section{Uji Koefisien Determinasi}

Berdasarkan hasil perhitungan statistik análisis regresi berganda menggunakan program statistik SPSS versi 19, diperoleh angka koefisien korelasi gabungan dan nilai R square, sebagai berikut.

Tabel 6 Nilai Koefisien Korelasi Gabungan dan R Square

\begin{tabular}{lcccc}
\multicolumn{1}{c}{ Variabel $^{*}$} & $\mathbf{R}$ & $\mathbf{R}^{2}$ & p-value & Keterangan \\
\hline $\begin{array}{l}\text { Motivasi, Kepuasan \& } \\
\text { Sikap kerja }\end{array}$ & 0,661 & 0,437 & 0,000 & Signifikan \\
\hline
\end{tabular}

(Sumber: hasil pengolahan data statistik, 2013)

Pengaruh gabungan motivasi, kepuasan, dan sikap kerja terhadap kinerja karyawan tergolong kuat. Besarnya dapat dilihat dari nilai $\mathrm{R}$ square 0,437 atau $43,7 \%$ kinerja karyawan dapat dijelaskan atau dipengaruhi oleh ketiga variabel moviasi, kepuasan, dan sikap kerja. Sedangkan sisanya 56,3\% dipengaruhi oleh variabel di luar ketiga variabel bebas yang disebutkan tadi.

Dari hasil besarnya kontribusi ketiga variabel motivasi, kepuasan, dan sikap kerja terhdap kinerja ini sudah seharusnya menjadi catatan manajemen Café X, bahwa kinerja karyawan paling tidak harus mendapat perhatian. Bagaimanapun, kesejahteraan karyawan menjadi faktor penting agar kinerja perusahaan secara keseluruhan bisa meningkat. Dengan jaminan penghidupan yang lebih layak dapat menjadi pemicu untuk bekerja lebih baik.

\section{Uji Simultan (Uji F)}

Dari hasil perhitungan SPSS diperoleh keluaran tabel sebagai berikut. 
Tabel 7 Hasil Uji Statistik F (uji F)

\begin{tabular}{lcccc}
\multirow{2}{*}{ Variabel Bebas } & \multicolumn{2}{c}{ Variabel Terikat (Kinerja Pegawai) } & \multirow{2}{*}{ Keterangan } \\
\cline { 2 - 3 } & F hitung & F Tabel & P-value & \multirow{2}{*}{ Sangat Signifikan } \\
\hline $\begin{array}{l}\text { Motivasi Kerja, Kepuasan } \\
\text { Kerja \& Sikap Kerja }\end{array}$ & 84,585 & 3,89 & 0,000 & \multirow{2}{*}{ Sangan } \\
\hline
\end{tabular}

(Sumber: hasil pengolahan data statistik, 2013)

Berdasarkan Tabel 7 tersebut, terlihat nilai $\mathrm{F}$ hitung 84,585> F tabel 3,89 atau menolak hipotesis nol dan menerima hipotesis altenatif yang menyatakan bahwa motivasi kerja, kepusan kerja, dan sikap kerja secara simultan berpengaruh terhadap kinerja pegawai. Artinya, naik turunnya kinerja pegawai tergantung pada motivasi, kepuasan kerja, dan sikap kerja dari para karyawan di Café X, Bogor.

\section{Uji Parsial (Uji t)}

Uji statistik $\mathrm{t}$ dilakukan untuk menguji signifikansi hubungan antarvariabel bebas dengan variabel terikat secara parsial, diperoleh data sebagai berikut.

Tabel 8 Hasil Uji Statistik t (Uji t)

\begin{tabular}{|c|c|c|c|c|}
\hline \multirow{2}{*}{ Variabel Bebas } & \multicolumn{3}{|c|}{ Variabel Terikat (Kinerja Pegawai) } & \multirow{2}{*}{ Keterangan } \\
\hline & t hitung & t Tabel $\left.{ }^{*}\right)$ & P-value & \\
\hline Motivasi Kerja & 2,943 & \multirow{3}{*}{2,069} & 0,008 & Signifikan \\
\hline Kepuasan Kerja & 0,778 & & 0,445 & Tidak Signifikan \\
\hline Sikap Kerja & 3,159 & & 0,005 & Signifikan \\
\hline
\end{tabular}

(Sumber: hasil pengolahan data statistic, 2013)

*) Nilai $t$ tabel diperoleh berdasarkan jumlah sampel 25 responden, dan derajat kebebasan $n-2=25-2=23$, maka pada toleransi alpha $5 \%$ untuk penelitian satu arah (one tailed) diperoleh nilai $t$ tabel $=2,069$.

Berdasarkan Tabel 8 tersebut, dapat dijelaskan bahwa uji hipotesis 1, variabel motivasi kerja memiliki t hitung 2,943 atau lebih besar dari t tabel 2,069 dengan probabilitas (p-value) 0,008 atau berarti menolak hipotesis nol dan menerima hipotesis alternatif yang menyatakan motivasi kerja berpengaruh positif terhadap kinerja pegawai. Uji hipotesis 2 , variabel kepuasan kerja memiliki $\mathrm{t}$ hitung 0,778 atau lebih kecil dari t tabel 2,069 dengan nilai signifikansi (p-value) sebesar 0,445 atau berarti menolak hipotesis alternatif dan menerima hipotesis nol yang menyatakan variabel kepuasan kerja tidak berpengaruh terhadap kinerja pegawai. Uji hipotesis 3, variabel sikap kerja memiliki $t$ hitung 3,159 atau lebih besar dari t tabel 2,069 dengan nilai signifikansi sebesar 0,005 atau berarti menolak hipotesis nol dan menerima hipotesis alternatif yang menyatakan variabel sikap kerja berpengaruh positif terhadap kinerja pegawai.

\section{Matrik Korelasi Antardimensi}

Untuk mengetahui dimensi variabel independen yang paling dominan dan besar pengaruhnya terhadap dimensi dari variabel dependen, maka digunakan matriks korelasi antardimensi. Dengan begitu pihak manajemen mempunyai gambaran untuk memutuskan langkah-langkah yang harus dilakukan agar performansi yang dihasilkan oleh karyawannya lebih meningkat lagi dari sebelumnya. Hal ini penting karena jika dimensi dari variabel meningkat, dimensi dari variabel dependennya akan meningkat pula sehingga peningkatan variabel dependennya akan makin besar pula. Adapun korelasi yang terjadi antardimensi dapat disajikan pada tabel berikut. 
Tabel 9 Matriks Korelasi Antardimensi ( $\alpha=5 \%)$

\begin{tabular}{|c|c|c|c|c|c|c|}
\hline \multirow{3}{*}{ Variabel } & \multirow[b]{3}{*}{ Dimensi X } & \multicolumn{5}{|c|}{ Kinerja Pegawai (Y) } \\
\hline & & $\begin{array}{c}\text { Kualitas } \\
\text { kerja }\end{array}$ & $\begin{array}{c}\text { Ketepatan } \\
\text { waktu }\end{array}$ & Efektivitas & Kemandirian & Komitmen \\
\hline & & $\left(Y_{1}\right)$ & $\left(Y_{2}\right)$ & $\left(Y_{3}\right)$ & $\left(Y_{4}\right)$ & $\left(Y_{5}\right)$ \\
\hline \multirow{4}{*}{$\begin{array}{c}\text { Motivasi } \\
\text { Kerja } \\
\left(\mathrm{X}_{1}\right)\end{array}$} & Aktualisasi diri $\left(\mathrm{X}_{11}\right)$ & 0.148 & 0.300 & 0.566 & 0.604 & 0.521 \\
\hline & Kebutuhan penghargaan $\left(\mathrm{X}_{12}\right)$ & 0.324 & 0.515 & 0.233 & 0.335 & 0.489 \\
\hline & Kebutuhan jaminan $\left(\mathrm{X}_{13}\right)$ & 0.275 & 0.268 & 0.421 & 0.553 & 0.521 \\
\hline & Kebutuhan fisik $\left(\mathrm{X}_{14}\right)$ & 0.621 & 0.556 & 0.418 & 0.465 & 0.578 \\
\hline \multirow{6}{*}{$\begin{array}{l}\text { Kepuasan } \\
\text { Kerja } \\
\quad\left(\mathrm{X}_{2}\right)\end{array}$} & Pekerjaan itu sendiri $\left(\mathrm{X}_{21}\right)$ & 0.273 & 0.221 & 0.325 & 0.445 & 0.285 \\
\hline & Kompensasi $\left(\mathrm{X}_{22}\right)$ & 0.280 & 0.351 & 0.451 & 0.454 & 0.412 \\
\hline & Promosi jabatan $\left(\mathrm{X}_{23}\right)$ & 0.124 & 0.251 & 0.316 & 0.450 & 0.436 \\
\hline & Supervisi (Atasan) $\left(\mathrm{X}_{24}\right)$ & 0.174 & 0.393 & 0.570 & 0.285 & 0.641 \\
\hline & Rekan kerja $\left(\mathrm{X}_{25}\right)$ & 0.288 & 0.384 & 0.707 & 0.532 & 0.536 \\
\hline & Kondisi kerja $\left(\mathrm{X}_{26}\right)$ & 0.211 & 0.522 & 0.316 & 0.666 & 0.352 \\
\hline \multirow{3}{*}{$\begin{array}{l}\text { Sikap } \\
\text { Kerja } \\
\quad\left(\mathrm{X}_{3}\right)\end{array}$} & Komponen afektif $\left(\mathrm{X}_{31}\right)$ & 0.460 & 0.520 & 0.488 & 0.431 & 0.335 \\
\hline & Komponen kognitif $\left(\mathrm{X}_{32}\right)$ & 0.587 & 0.568 & 0.414 & 0.435 & 0.361 \\
\hline & Komponen perilaku $\left(\mathrm{X}_{33}\right)$ & 0.252 & 0.203 & 0.573 & 0.529 & 0.479 \\
\hline
\end{tabular}

(Sumber: hasil pengolahan data statistik, 2013)

Berdasarkan Tabel 9 di atas dapat dijelaskan sebagai berikut: Pertama, motivasi kerja terhadap kinerja karyawan, dari data tersebut diperoleh nilai korelasi yang paling besar ditemukan pada hubungan dimensi kebutuhan fisik dengan dimensi kualitas kerja sebesar 0,621. Kondisi seperti ini menunjukkan bahwa kebutuhan fisik pada karyawan berkaitan erat dengan kualitas kerja karyawan bekerja. Sehingga dapat dijelaskan bahwa jika tingkat pemenuhan kebutuhan dasar seperti sandang, pangan, dan papan meningkat, kualitas kerja karyawan juga akan meningkat. Bagaimanapun, kebutuhan dasar adalah sebuah variabel yang dapat memberi ketenangan dalam hidup. Sedangkan faktor yang paling rendah adalah dimensi aktualisasi diri dengan nilai koefisien 0,148 . Hal ini menunjukkan pencapaian potensi diri atau pemenuhuan kebutuhan diri yang rendah. Maslow dalam Robbins (2007) menyatakan bahwa manusia dimotivasi untuk memuaskan sejumlah kebutuhan yang melekat pada diri setiap manusia yang cenderung bersifat bawaan.Sekali suatu kebutuhan terpuaskan, maka motivasinya akan meningkat. Sebaliknya, apabila kinerja karyawan rendah, maka salah satunya harus dilihat dari faktor seperti pemenuhan kebutuhan.

Kedua, pengaruh kepuasan kerja terhadap kinerja karyawan, berdasarkan data diperoleh nilai korelasi yang paling besar untuk variabel kepuasan pada hubungan dimensi kompensasi dengan kemandirian yaitu sebesar 0,454 . Hal ini menunjukkan bahwa meskipun secara kompensasi karyawan kurang puas, dalam bekerja tetap mampu mandiri. Jika kepuasan kerja karyawan rendah, akan menimbulkan kondisi buruk dalam mencapai tujuan perusahaan sehingga tidak dapat bersaing dengan perusahaan lain. Sedangkan faktor yang paling rendah adalah dimensi promosi jabatan dengan nilai koefisien korelasi 0,124. Keadaan ini sejalan dengan realitas di tempat kerja, bahwa hampir sebagian besar pegawai tidak memiliki atau tidak terlalu berharap terhadap promosi jabatan, karena sifat dari pekerjaan yang kurang mendukung.

Ketiga, pengaruh sikap terhadap kinerja karyawan, berdasarkan Tabel 9 dapat dilihat bahwa nilai korelasi yang paling besar ada pada dimensi hubungan antara komponen kognitif dengan kualitas kerja, yaitu sebesar 0,587. Suatu keadaan yang menunjukkan adanya pemahaman yang dimiliki karyawan terhadap pekerjaan cukup baik. Makin baik komponen kognitif, maka akan makin baik pula kualitas pekerjaan karyawan. Sedangkan dimensi yang paling rendah adalah komponen perilaku dengan koefisien 0,203 atau adanya kecendrungan perilaku yang cenderung berubah terhadap permasalahan atau objek di tempat kerja. 
Temuan penelitian ini menegaskan bahwa dari ketiga variabel bebas yang diteliti hanya variabel sikap kerja dan motivasi kerja yang memiliki pengaruh positif terhadap kinerja pegawai. Sedangkan variabel kepuasan kerja tidak memiliki pengaruh positif terhadap kinerja pegawai. Hal ini menunjukkan bahwa ada rasa ketidakpuasan di sebagian besar pegawai, terutama karena faktor gaji yang diterima dianggap belum memenuhi kebutuhan minimum para pegawai. Ditambah lagi tidak adanya insentif yang diberikan manajemen restoran kepada para pegawai. Pegawai terkadang hanya menerima uang tip dari para tamu restoran yang datang.

Sedangkan pengaruh sikap kerja dan motivasi kerja berpengaruh positif terhadap kinerja pegawai dapat dijelaskan bahwa para pegawai cenderung hanya untuk merespons terhadap hal-hal yang menyenangkan dari kondisi tempat kerja. Para pegawai juga masih memiliki keyakinan dan pemikiran berperilaku yang baik terhadap pekerjaan dan menghargai manajemen restoran. Begitu pula motivasi para pegawai, di sini para pegawai masih memiliki motivasi untuk tetap bekerja sebagai karyawan di restoran tersebut sesuai standar manajemen, ada rasa senang bekerja dan merasa tidak memiliki pilihan lain selain bekerja di tempat kerja sekarang.

Hasil penelitian ini bisa diinterpretasi oleh manajemen restoran dengan mempertimbangkan beberapa keterbatasan. Pertama, data yang dikumpulkan hanya dari pegawai di Café X, Bogor sehingga belum bisa mencerminkan persepsi pegawai di setiap restoran secara keseluruhan. Kedua, penelitian dilakukan pada beberapa posisi atau bagian sehingga simpulan hasil penelitian belum bisa digeneralisasi pada semua posisi yang ada di restoran tersebut. Ketiga, variabel-variabel yang dimasukkan belum tentu mencerminkan faktor utama dari penilaian responden. Selain itu, studi ini bukanlah studi eksperimen yang detail, sehingga masih dimungkinkan ada variabel yang belum teridentifikasi atau ada variabel yang tidak diinginkan menurut persepsi responden. Oleh karena itu, penelitian selanjutnya mungkin bisa mempertimbangkan rekomendasi penelitian untuk menarik kesimpulan penyebab yang lebih meyakinkan.

\section{SIMPULAN}

Berdasarkan pada hasil penelitian dan pembahasan dapat disimpulkan beberapa hal sebagai berikut. Hipotesa pertama membuktikan adanya pengaruh positif antara motivasi kerja terhadap kinerja karyawan di Cafe X. Hasil penelitian ini sejalan dengan penelitian yang dilakukan Sharma dan Bharti (2012), yang dalam penelitiannya disebutkan terdapat pengaruh motivasi pegawai terhadap kinerja (produktivitas) pada perusahaan swasta. Adanya pengaruh motivasi tersebut didukung dari tanggapan para karyawan terutama karena faktor kebutuhan fisik. Alasan kebutuhan fisik ini dianggap merupakan kebutuhan penting bagi para pegawai yang dapat memicu semangat untuk terus bekerja.

Hipotesis kedua menunjukkan bahwa tidak ada pengaruh kepuasan kerja terhadap kinerja karyawan, sehingga hipotesis kedua tidak terbukti. Hasil penelitian ini tidak sejalan dengan penelitian yang dilakukan Judge dan Timothy (2004) yang menjelaskan kepuasan kerja berpengaruh penting terhadap kinerja karyawan. Tidak berpengaruhnya kepuasan kerja terhadap kinerja karyawan ini disebabkan rendahnya gaji dan tunjangan serta tidak adanya insentif dan tidak adanya peluang karier dan promosi jabatan.

Hipotesa ketiga membuktikan adanya pengaruh positif dari sikap kerja terhadap kinerja karyawan. Dalam hal ini komponen kognitif seperti pemahaman dan pengetahuan karyawan terhadap pekerjaan cukup baik. Makin baik komponen kognitif, akan makin baik pula kualitas pekerjaan karyawan. Sedangkan komponen perilaku dari sikap kerja paling rendah korelasinya dengan kinerja karyawan atau adanya kecendrungan perilaku yang cenderung berubah terhadap permasalahan atau objek di tempat kerja. Hasil penelitian ini sejalan dengan pendapat Chen dan Silverthorne (2008) yang 
menyatakan pegawai yang memiliki sikap dan tanggung jawab sepenuhnya dari pekerjaan memiliki kaitan terhadap kinerja karyawan.

Hipotesis keempat menunjukkan adanya pengaruh gabungan terhadap kinerja karyawan, dan dari hasil pengujian statistik secara parsial, membuktikan bahwa hanya variabel sikap kerja dan motivasi kerja yang memiliki pengaruh positif terhadap kinerja karyawan, kecuali variabel kepuasan kerja. Ini artinya bahwa fakta empiris berdasarkan hasil penelitian yang dilakukan mengenai kinerja karyawan Café X lebih cenderung dipengaruhi oleh kedua variabel sikap dan motivasi kerja.

\section{DAFTAR PUSTAKA}

Anogara, P. (2006). Psikologi Kerja. Jakarta: Rineka Cipta.

Chen, J. C. and Siverthorne, C. (2008). The impact of locus of control on job stress, job performance and job satisfaction in Taiwan. Emerald Insight, pp. 572-582.

George and Jones. (2005). Understanding and Managing Organizatiional Behaviour. 4th Edition. Prentice Hall.

Ghozali, I. (2005). Aplikasi Analisis Multivariate Dengan Program SPSS. Semarang: Universitas Diponegoro.

Judge, L. M. and Timothy. (2004). Employee attitudes and Job Satisfaction. Human Resource Management, pp. 395-407.

Kreitner and Kinicki. (2008). Organization Behaviour 8th Edition. McGraw Hill International.

Mangkunegara, A. P. (2002). Manajemen Sumber Daya Manusia Perusahaan. Bandung: Remaja Rosdakarya.

Munandar, A. S. (2008). Psikologi Industri dan Organisasi. Jakarta: UI Press.

Nawawi, H. (2005). Metodologi Penelitian Bidang Sosial. Yogyakarta: Gajah Mada Universitas Press.

Robbins, S. P. and Judge, T. A. (2007). Organizational Behaviour. 12th Edition. Prentice Hall International.

Sharma, N. C. and Bharti. (2012). Pengaruh Motivasi pegawai terhadap Kinerja (produktivitas) pada perusahaan Swasta. International Journal of Business Trends and Technology.

Wood, J., Wallace, J. and Aeffane, R. M. (2001). Organizational Behaviour: A Global Perspective 2nd Edition. New Jersey: John Willey and Sons. 